\title{
極厚 $\mathrm{H}$ 形鋼を用いた鋼構造柱はり接合部の 力学的性状に関する実験的研究
}

\section{1. 序}

最近，超高層建築物の設計にあたって構造部材に極厚 $\mathrm{H}$ 形鋼を用いる例が多いが，一方では極厚 $\mathrm{H}$ 形鋼を用 いた柱・はり接合部の実大実験に扔いて，脆性破壊が発 生した，という報告もある1)。鋼構造物の脆性破壊はこ れまで一般に低温において問題にされていたが，それが 常温において発生したということは，脆性破壊の発生が 部材変形のあまり大きくない段階で生じるものであるだ 汀構造設計上，大きな問題を提起 していることにな る。加藤博士らはその原因として部材の剛性が著しく大

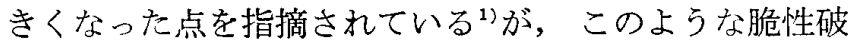
壊の発生は接合部の形状寸法, 鋼材の材質, 溶接方法, 溶接条件等によっても影響されるものと考えられ，また 実験例もこれまでは，まだ，この一例しか報告されてい ないので，その詳細については不明な点が多い。今後の 設計においては，前記の実験結果で報告されている板厚 よりもさらに板厚の大きい部材を用いることも予想さ れ，構造設計上からもこのような問題点を検討しておく ことが必要となろう。

また，脆性破壊の発生が拘束条件の厳しい個所におい て起りやすいことを考えると骨組の構成部材として極厚 材を用いた場合，接合部パネルを完全に補剛することに ついても問題が残る。すなわち一般に接合部パネルの降 伏耐力と最大耐力の間には耐力的にも, 変形的にも十分 な余裕があるので，この上うな場合の骨組の設計方針と して，むしろ接合部パネルを補剛せず，早期に降伏させ 接合部パネル周辺の変形拘束をある程度緩和して脆性破 壊の発生を避けるなり，その時期を遅らせることも一つ の設計方針と考えられる。

このような観点から，柱・はり部材に極厚 $\mathrm{H}$ 形鋼を 用いて，接合部パネルの耐力，変形性状，およびそれが

*大成建設 (株) 総合企画本部長付

** 大成建設 (株) 技術研究所 粠造研究室長

*** 大成建設 (株) 技術研究所 主任研究員 工博

*****大成建設 (株) 東京支店

(昭和 48 年 3 月 27 日本稿受理 ・討諭期限昭和 48 年 11 月末日)

$\begin{array}{lllll}\text { 正会員 } & \text { 竹 } & \text { 波 } & \text { 正 } & \text { 洪* } \\ \text { 正会員 } & \text { 斎 } & \text { 藤 } & \text { 辰 } & \text { 彦*** } \\ \text { 正会員 } & \text { 田 } & \text { 中 } & \text { 渟 } & \text { 夫**** } \\ \text { 正会員 } & \text { 榎 } & \text { 本 } & \text { 憲 } & \text { 正***** }\end{array}$

周辺部材におよぼす影響，骨組としての最終的な破壊状 況などの力学的諸性状の把握を主目的として実大実験を 行なったのでこここ報告する。

なお，本論文では塑性域に人ってから大きな変形を示 さずに脆性的に破壊する現象を脆性破壊と総称してい る。詳細にみれば，個々のケ一スで塑性に入ってから破 断までの変形状況, きれつ伝播の状況, 破面に㧍けるシ 中ーリップの割合などが異なっているが，いずれも明ら かな脆性破面が認放られるもので，建築構造物として は，望ましくない破壊形態と考えら机るものである。

\section{2. 実 験 概 要}

\section{1 試 験 体}

本実験では上述の実験目的にかんがみ，試験体を構成 する柱，はり部材はともに極厚 $\mathrm{H}$ 形鋼を用いた。その極 厚 $\mathrm{H}$ 形鋼はすべて 400 シリーズと呼ばれる系列の広幅形 鋼であり，フランジ内法寸法 $(358 \mathrm{~mm})$ およびフランジ 幅からウェブ厚を引いた寸法が一定 $(387 \mathrm{~mm})$ で，フラ ンジ厚，ウェブ厚のみが変化しているものである。そこ で以下の文中ではこれらをウェブ厚/フランジ厚のみの 表示で略記する。

柱部材としては，40/75，65/90，90/125 の3 種類を 選び，接合部パネルの耐力がはり部材の耐力の $1 / 2$ 前後 になるよう，はり部材としては前 2 者に対して $25 / 40$ を，90/125 に対しては 40/60を採用した。40/75 と 25/40 の組合わせでは，接合部パネルの降伏耐力がはり の降伏耐力の約 $1 / 3$ となるので，この組合わせについて は接合部パネルに両面から補強プレート（也-22）を溶接 して接合部パネルの体積をほぼ倍增した試験体を作成 し，補強の効果を検討した。試験体の形状は載荷の容易 ないわゆる X 型とし，柱部材，はり部材とも加力点閒 距離を等しくした。

はりフランジと柱フランジとの溶接には，手溶接，消 耗ノズル式エレクトロスラグ溶接（以下本報告で汢これ を単にエレクトロスラグ溶接という)，およびエレクト ロスラグ溶接をしたあと，溶接止端部に強度は幾分低い 
が伸びの良い低水素系溶接棒を用いた手溶接による補強 盛を行なら方法の 3 種類を採用した。

結局, 変化要因は次の 3 つである(下記のカッコ内の アルファベットは試験体に用いた記号を示す)。

(i) 柱，はり部材の組合わせとして，40/75 と 25/ 40 (A), $65 / 90$ と $25 / 40$ (B), $90 / 125$ と $40 / 60$ (C) の 3 種.

（ii）接合部パネルを補強したもの（補強方法は，柱 フランジとダイヤフラムに囲まれる接合部パネル部分の みにその両側から，すみ肉溶接の脚長分だけ小さい寸法 の補強プレートをあて, その周辺を柱ウェブにすみ肉溶 接するものである。）(D) と無補強のもの（S）の 2 種.

(iii）はりフランジの溶接法として，手溶接を用いた もの（a），エレクトロスラグ溶接を用いたもの（e)，エ レクトロスラグ溶接に手溶接による補強盛をしたもの (ea) の 3 種.

試験体は上記の 3 要素を適宜組合わせた XA-Sa, $\mathrm{XA}-\mathrm{Da}, \mathrm{XB}-\mathrm{Sa}, \mathrm{XB}-\mathrm{Se}, \mathrm{XB}-\mathrm{Sea}, \mathrm{XC}-\mathrm{Se}$ (最初の X はX型試験体であることを示す記号）の計 6 体である。

試験体の形状と寸法は図一1 に示す。試験体名称と使 用した極厚 $\mathrm{H}$ 形鋼，溶接方法の組合わせを表一1 にま とめた。柱フランジとはりフランジの突合わせ溶接部の 溶接条件は表一2 に示す。

使用した極厚 $\mathrm{H}$ 形鋼の化学成分を表一 3 に，その機 械的性質を表一 4 亿示す。極厚 $\mathrm{H}$ 形鋼では試験片の採 取位置により，また採取方向により機械的性質にある程 度の差があるものと考え, 断面内の各点について検討し
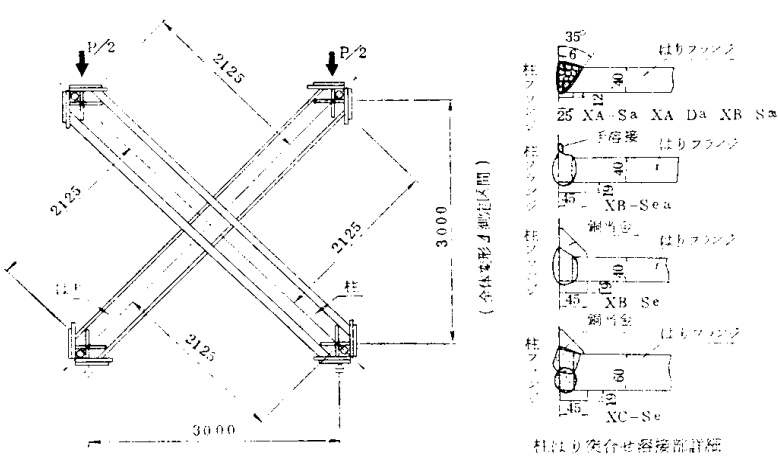

図-1

たが，当然想定される板厚方向の伸びおよび衝撃值以外 は，大きな差のないことが確認されたので，ここに沬代 表值として，表一4 の付図に示す採取位置の圧延方向の 值だけを示した。

材質はダイヤフラム，補強用プレートと $25 / 40$ の $\mathrm{H}$ 形鋼が SM 50 A であるほかすべて SM 50 B である。

2.2 実験方法

実験には東大工学部綜合試験所の $2000 \mathrm{t}$ 万能試験機 を使用し，図一1に示す如く加力した。柱・はりにほぼ 同量の軸力, 曲げが作用することになる。支点, 加力点 にはテフロン支承を用いてローラー支持の条件を満すべ く考慮してある。XA シリーズの加力は接合部パネルゾ ーンのせん断角変形が塑性率で 2 と 4 になる荷重で正負 の繰返しを一度ずつ行なった後に破壊に至らしめた。そ の他の試験体では, さらにパネルゾーンの変形の塑性率 が 8 になる荷重でもら一度正負の繰返し加力を行なった 後に最大荷重まで加力した。

験体

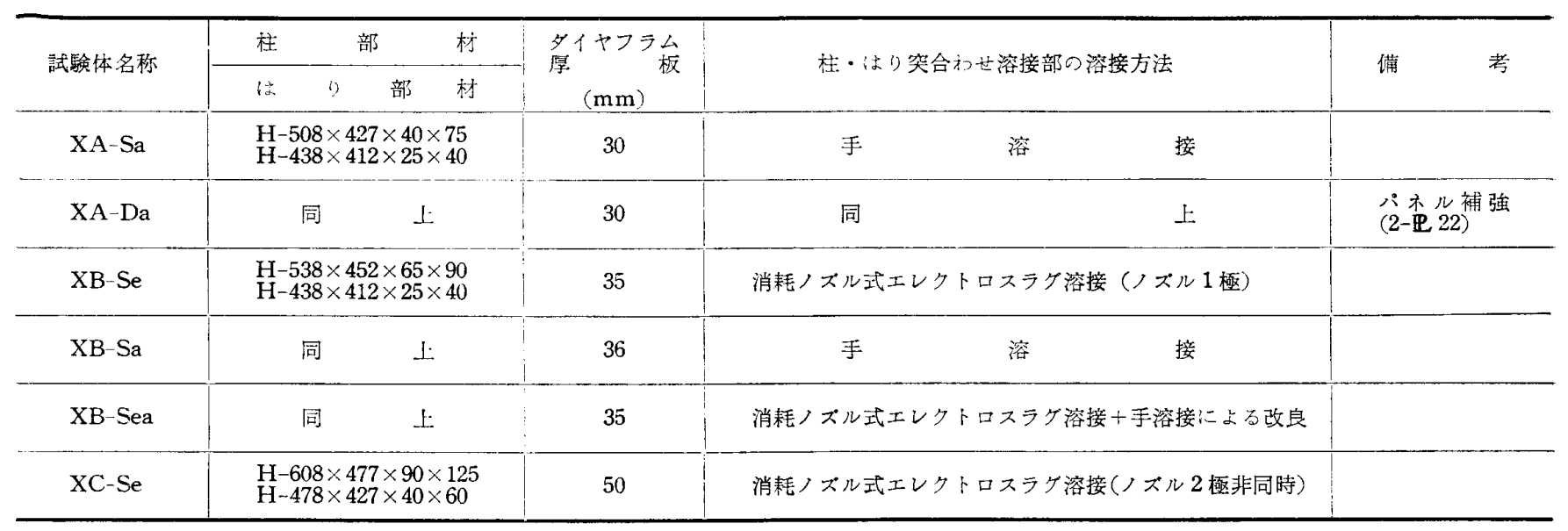

表一-2 溶接条件（柱とはりの突合わせ溶接部）

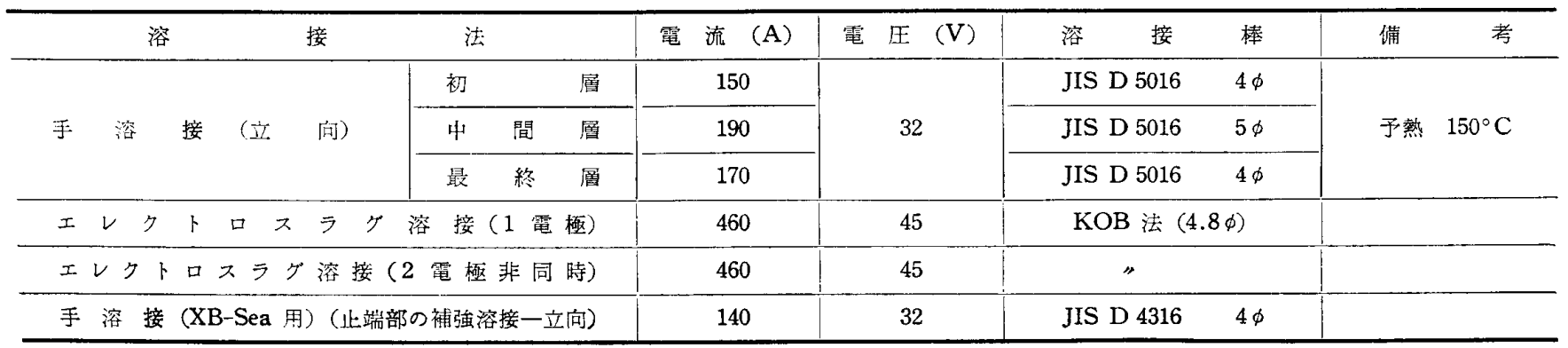


表一3 極厭 $\mathrm{H}$ 形鋼 $の$ 化学成分

\begin{tabular}{|c|c|c|c|c|c|c|}
\hline 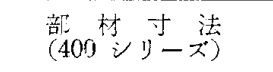 & $\mathrm{C} \quad(\%)$ & $\mathrm{Si} \quad(\%)$ & $\mathrm{Mn} \quad(\%)$ & $\mathrm{P} \quad(\%)$ & $\mathrm{S} \quad(\%)$ & Ceq* \\
\hline $\begin{array}{c}25 / 40, \quad 40 / 60 \\
40 / 75, \quad 65 / 90,90 / 125\end{array}$ & $\begin{array}{l}0.18 \\
0.18\end{array}$ & $\begin{array}{l}0.40 \\
0.39\end{array}$ & $\begin{array}{l}1.31 \\
1.30\end{array}$ & $\begin{array}{l}0.015 \\
0.014\end{array}$ & $\begin{array}{l}0.008 \\
0.007\end{array}$ & $\begin{array}{l}0.415 \\
0.413\end{array}$ \\
\hline
\end{tabular}

表-4 極原 $\mathrm{H}$ 形鋼 $の$ 機械的性質

\begin{tabular}{|c|c|c|c|c|c|c|c|c|c|}
\hline 部材寸法 & 試䮖片探取位置 & $\begin{array}{c}\text { 降 伏 点 } \\
\left(\mathrm{kg} / \mathrm{mm}^{2}\right) \\
\end{array}$ & $\begin{array}{c}\text { 引張強さ } \\
\left(\mathrm{kg} / \mathrm{mm}^{2}\right)\end{array}$ & 伸 & ¿ & $(\%)$ & ) & 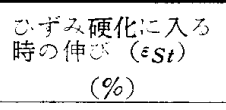 & 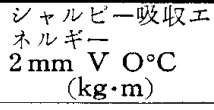 \\
\hline $25: 40$ & $\begin{array}{l}\mathrm{F} \\
\mathrm{W}\end{array}$ & $\begin{array}{l}34.2 \\
37.5\end{array}$ & $\begin{array}{l}52.3 \\
54.2\end{array}$ & $\begin{array}{l}32.4 \\
30.4\end{array}$ & & $\begin{array}{l}75 \\
71\end{array}$ & & $\overline{1.66}$ & - \\
\hline 40,60 & $\begin{array}{l}F \\
W\end{array}$ & $\begin{array}{l}35.4 \\
34.9\end{array}$ & $\begin{array}{l}57.4 \\
54.2\end{array}$ & $\begin{array}{l}30.2 \\
31.2\end{array}$ & & $\begin{array}{l}73 \\
73\end{array}$ & & $\begin{array}{l}0.64 \\
1.02\end{array}$ & - \\
\hline $40: 75$ & $\begin{array}{l}\mathrm{F} \\
\mathrm{W}\end{array}$ & $\begin{array}{l}31.0 \\
33.1\end{array}$ & $\begin{array}{l}53.7 \\
54.0\end{array}$ & $\begin{array}{l}32.2 \\
32.0\end{array}$ & & $\begin{array}{l}74 \\
74\end{array}$ & & $\begin{array}{l}0.80 \\
1.14\end{array}$ & 8.0 \\
\hline $65 / 90$ & $\begin{array}{l}F \\
W\end{array}$ & $\begin{array}{l}30.2 \\
31.5\end{array}$ & $\begin{array}{l}52.0 \\
52.0\end{array}$ & $\begin{array}{l}32.4 \\
32.4\end{array}$ & & $\begin{array}{l}73 \\
73\end{array}$ & & $\begin{array}{l}0.86 \\
1.32\end{array}$ & 10.0 \\
\hline $90: 125$ & $\begin{array}{l}F \\
W\end{array}$ & $\begin{array}{l}30.3 \\
31.2\end{array}$ & $\begin{array}{l}52.6 \\
52.6\end{array}$ & $\begin{array}{l}32.4 \\
32.2\end{array}$ & & $\begin{array}{l}72 \\
72\end{array}$ & & $\begin{array}{l}0.86 \\
1.00\end{array}$ & 7.5 \\
\hline
\end{tabular}

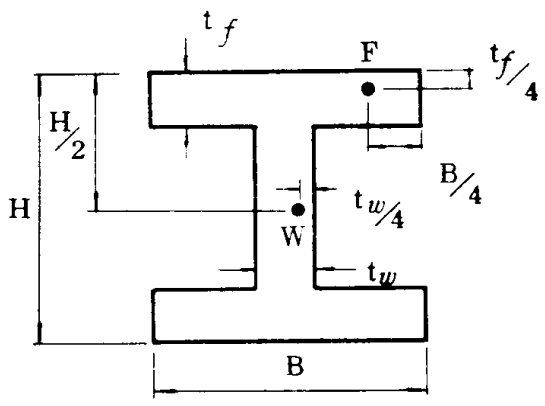

接合部パネルのせん断変形角は柱はり突合わせ溶接部 の外側からバネル対角線方向の変位として, また架構全 体の変形は図-1 に示古測定区間について，それぞれ 1/100 mm 目盛のダイヤルゲージを用いて測定した。接 合部パネル内部およびその周辺の応力分布についても, 電気抵抗線ひずみゲージを使用して測定した。

\section{3. 実験 結果}

3.1 実験経過と破断状況

耐力，変形，破断状況等の実験結果は表一 5 にまとめ た。

XA-Sa, XB-Sa XB-Se, XC-Se, の 4 体の試験体で は接合部パネル周辺で大きな塑性変形を示さぬらちに脆 性的な破壊が生じて耐力がきまっている。 XA-Da，

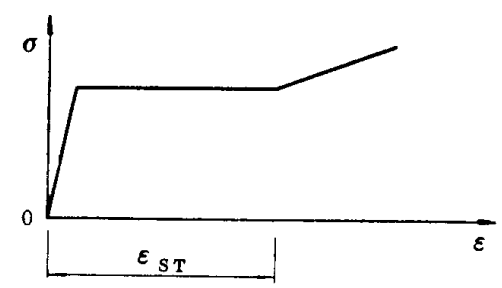

XB-Sea では接合部パネル，柱，はり部材が十分な変形 を示したと考えられるまで加力したが，それ以上は実験 装置の都合上加力することが出来なくなり，結局どこに も大きな破壊は生じすにに実験を終えた。

次に各試験体の最終時の状況，とくにきれつ発生の状 況を記す。

$\mathrm{XA}-\mathrm{Sa}$ : 最終加力時に大きな音を発してパネルゾ一 ン中央ほぼ詨角線上にきれつが発生した。このきれつは 幅が約 $3 \mathrm{~mm}$ 程度で, ダイヤフラムと柱フランジの溶接 部を通って柱フランジ内部まで達していた（写真一1）。

$\mathrm{XA}-\mathrm{Da}$ ：最終荷重時まで溶接部やパネルゾーンは健 全できれつの存在は認められず，はりウェブのスカラッ プ端にわずかにきれつの存在が認められただけである。

表一5 実験給果

\begin{tabular}{|c|c|c|c|c|c|c|c|c|c|}
\hline \multirow{2}{*}{ 圾 験 体 } & 耐 & 力 & ton) & 変 & 形 & 最 & 塑 & 率 & \multirow{2}{*}{ 破 断 状 況 } \\
\hline & $P_{P y}$ & $P_{B y}$ & $P_{\max }$ & $\left(\begin{array}{c}r \max \\
\left.\times 10^{-3} \mathrm{rad}\right)\end{array}\right.$ & $\begin{array}{l}\Delta_{\max } \\
\quad(\mathrm{mm})\end{array}$ & $\mu_{P \max }$ & $\mu_{B \max }$ & $\mu_{d \max }$ & \\
\hline $\mathrm{XA}-\mathrm{Sa}$ & 108 & 240 & 309 & 35.5 & 94 & 21 & 3 & 13 & 接合部パホル破壤 \\
\hline $\mathrm{XA}-\mathrm{Da}$ & 190 & 310 & $>480$ & 61.0 & 224 & $>41$ & $>15$ & 18 & 破断せず \\
\hline $\mathrm{XB}-\mathrm{Sa}$ & 158 & 320 & 455 & 45.1 & 116 & $>30$ & 7 & 11 & はっ・柱溶接部破断 \\
\hline XB-Se & 174 & 300 & 420 & 15.4 & 50 & $>13$ & 3 & 5 & " \\
\hline XB-Sea & 178 & 325 & $>495$ & 82.7 & 249 & $>65$ & $>14$ & 20 & 破断せナ゙ \\
\hline $\mathrm{XC}-\mathrm{Se}$ & 300 & 460 & 775 & 20.3 & 86 & $>16$ & 7 & 8 & 杜り・柱溶接部破断 \\
\hline
\end{tabular}




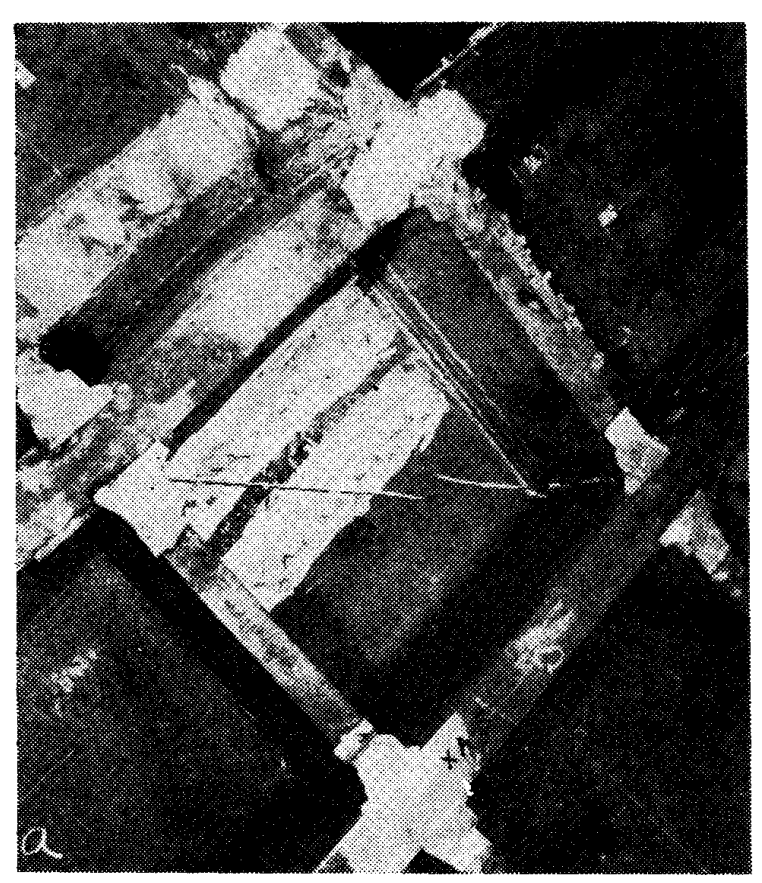

写真一1 XA-Sa パネル破断状況

XB-Se : 最終加打を行なって, 試験機の送り弁を止 わた直後に柱，はり突合わせ溶接部の柱側止端部よりき れつが発生した。破断時の音は小さく，きれつも熱影響 部にそって，20 mm 程度柱フランジ内に伝播したとこ ろで停止していた（写真一2）。

XB-Sa : 一度最大荷重 $(455 \mathrm{t}$ ) まで加力したあとで除 荷し，実験装置を盛替えて再び加力した際，その途中で

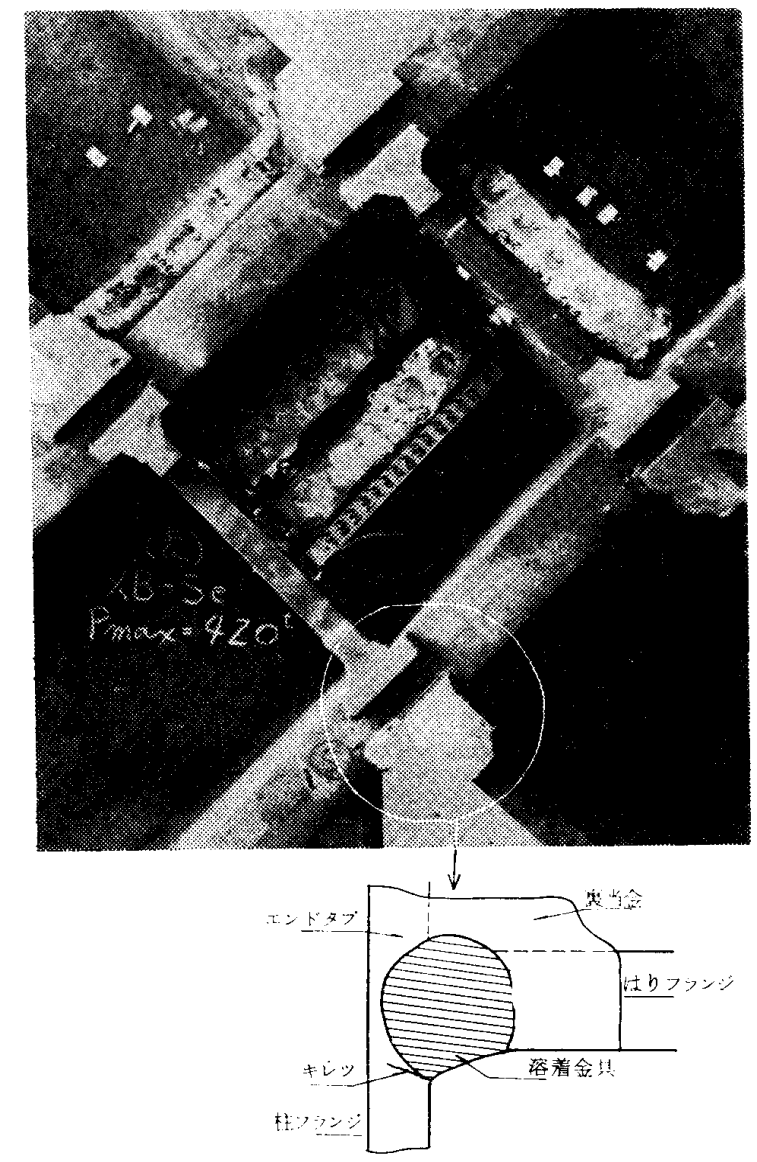

写直－2 XB-Se 溶接部破断状況
前回最大荷重よりやや低い荷重 $(447 \mathrm{t}$ ) で，かなりの音 を発して柱，はり突合わせ溶接部の柱側止端部よりきれ つが発生した。このきれつはほぼ柱フランジ在貫通した ところで停止している（写真-3）。

XB-Sea：きれつの発生は認められず，実娩終了まで 試験体は健全であった。

$\mathrm{XC}-\mathrm{Se}$ : 最終加力の途中で張側はりフランジと柱と の溶接部が大音響を伴なって破断した。破断箇所を調心゙ たところ，きれつは突合わせ溶接部の柱側止端部上り溶 接の熱影響部にそってはしり，引張側の柱フランジを貫 通後 2 つに分れ，1つはダイヤフラムにそって柱りェブ を横断し，圧縮側フランジにまで達し，1 つは杜フラン ジをひきはがすように再び引張側柱フランジの表而に出 て，はりフランジの庄縮側のスカラッブのしころをで逆 して扮り，典型的な脆性破的走呈してい:（学真一4）。 3.2 測定結果

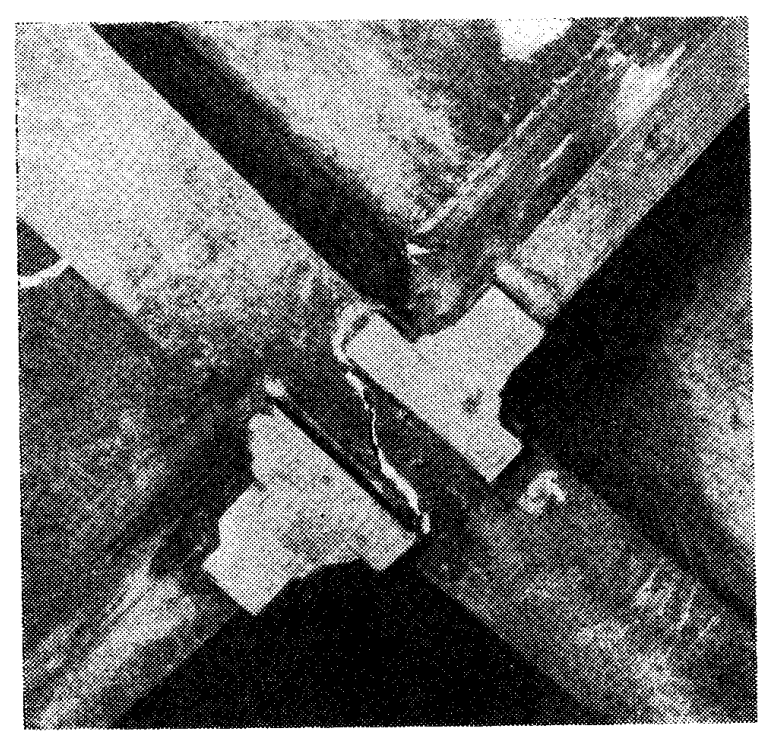

写真一3 XB-Sa 柱フランジ破断状沉

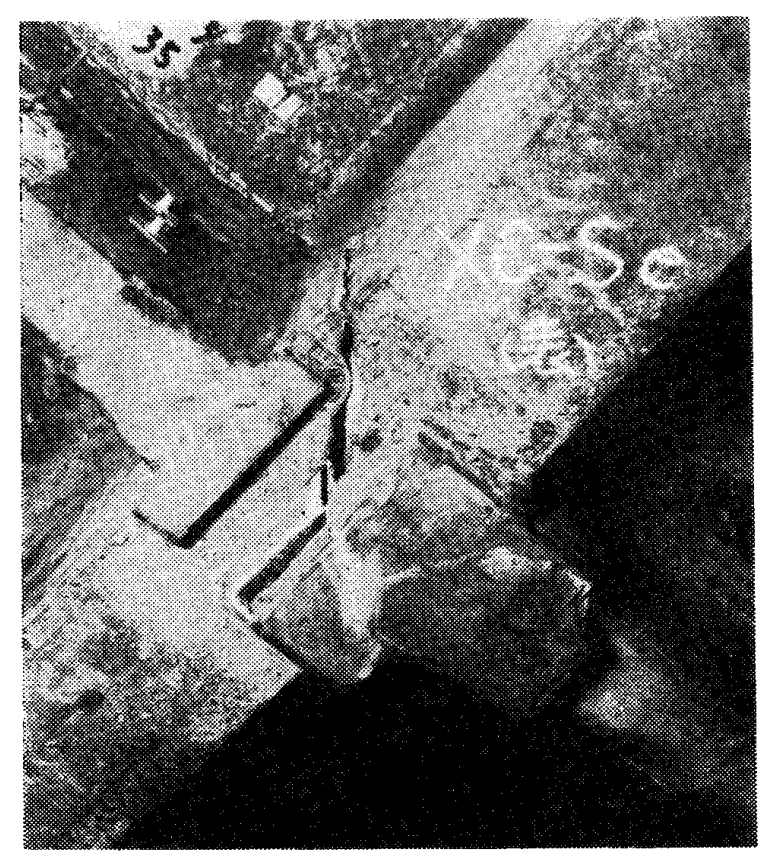

写真一4 XC-Se 柱フランジ破断状況 


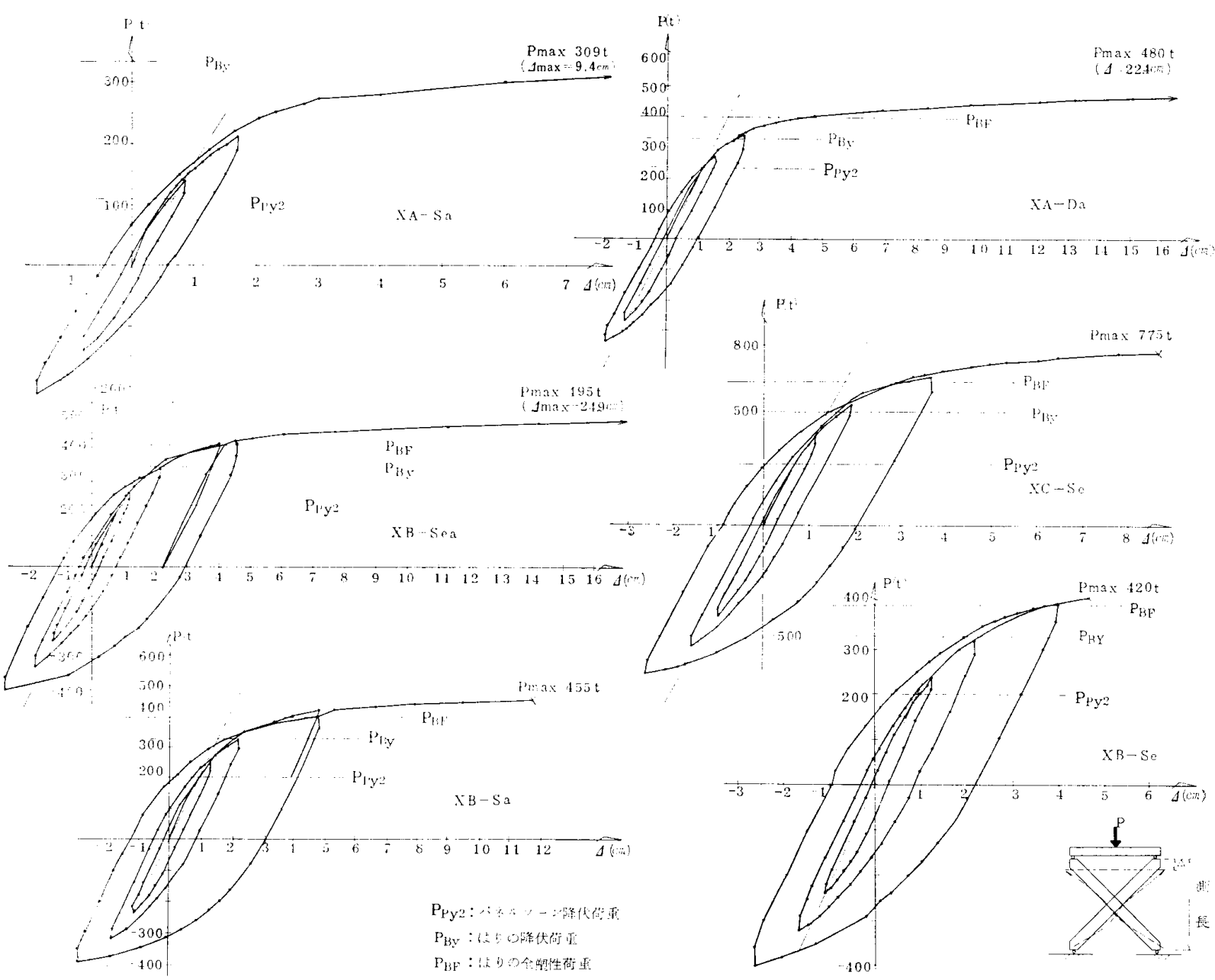

図一2

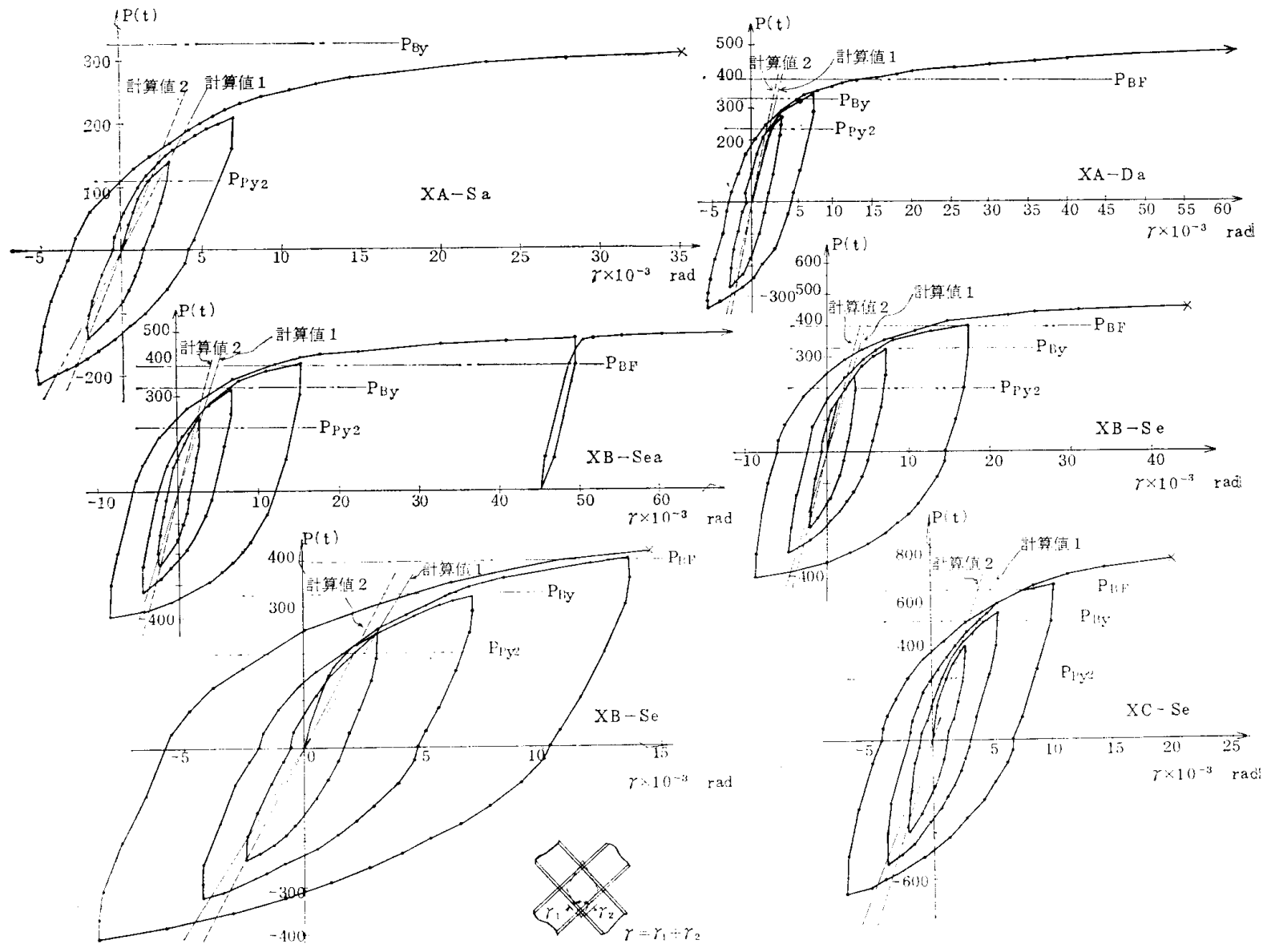


試験体の全体変形 $(A)$ と荷重 $(P)$ の関係を龱一2 に, 接合部パネルゾーンせん断角変形の履歴曲線 $(P \sim \gamma$ 関係）を図一3 に示す。

\section{4. 実験結果の検討と考察}

4.1 パネルゾーンの雱力と変形

4.1 .1 耐 力

本実験の場合，接合部パネルに対する軸力の影響恃き わわて小さいので, 外力によるせん断応力だけを考虑し て, 各試験体の接合部パネルの降伏荷重 $P_{P y}$ を計算し, その結果を表一6 に示す。極厚 $\mathrm{H}$ 形鋼を用いた接合部 パネルでは, 設計の際, その領域としてパネルの外周線 を柱フランジおよびダイヤフラムの外面によるか，それ らの中心線にとるか，内面にとるかで耐力算定值に大き な差が生じる。このような意味で表一6には上述の各ケ 一スについて，パネル内の忘力分布を均等とした場合の 計算值が示してある。さらにこれらとの比較のため日本 建築学会「鋼構造設計規準」の解説に示寸設計式による 計算值（パネル領域は各板の中心線内）も示した。これ らの值を表一5 の実験值と比較すると, 試験体のタイプ こよって幾分かの差はあるが，全体としては各板の中心 線内を領域とする計算值が実験值に近い值となっている ことが判る。この実験值は general yield point 法で求 めた一応の目安というべき值であるので, 数值同志の比 較だけでは問題が残る。そこで図一-3のP P-r関係にこ の計算值 $P_{P_{y 2}}$ を記入したが，これをみるとやはりこの 計算值が実験結果を適正に評価しているとみることがで きよう。また「鋼構造設計規準」による值はここの計算 值より幾分大きめではあるが，設計值としてとる場合に は一応妥当なものであるといえよう。

本実験において，接合部パネルの最大耐力が得られた のはXA-Sa だけである。通常の鋼構造の柱はり溶接部 では，パネルの板厚がその幅や長さに比べてかなり小さ いために，その最大耐力は座屈できまる例が多い。しか し杜に極厚 $\mathrm{H}$ 形鋼を用いた場合には，パネルの幅厚比 が小さくなるため，パネルが座屈を起こす可能性が小さ
くなりむしろパネルゾーン内の引張応力が材の破断強 度に達して最大耐力がきまることが考えられ，XA-Sa もこのタイプの破断状況を呈したものと思执る（写 真一1）。このような意味で，パネルゾーンを柱フランジ とダイヤフラムの板厚の中心線で囲まれた範囲之し，作 用せん断力だけを対象に平均せん断応力度に基づいて求 めた，最大荷重時における接合部パネル内の主応力值を 求め，表一6 に示してある。これをみるこXA-Sa の注 忘力計算值は，母材の引張強さに丁度等しくなっている ことが認められる。本実験で扱っている接合部バネルゾ 一ン内部は，柱，はりからの軸方向力の影響がきわめて 小さいので，溶接部パネルゾーン内を純せん断の状態と みても大差はなく，また発生したきれつの方向も純せん 断状態の引張主応力に対してほぼ直角方向であることか ら，XA-Sa におけるきれつはこの引張主応力によって 発生したものと考えることができる。全試娩体中 4 体に ついてこの $\sigma_{\max } / \sigma_{B}$ が $0.96 \sim 1.00$ の範囲に市るなか で，パネルゾーンで破壊した試験体は XA-Sa 1 体だけ であったことからいえばこの仮定が実情に合うし即断す ることはできないが，パネルゾーンの最大耐力の一応の 目安を得るためには参考になるものと思われる。

\section{1 .2 変 形}

せん断変形のみを考えた弾性範囲内の変形計算值を 図一3 に計算值として 1 点鎖点で示した。これはパネル ゾーンの領域として，柱フランジ㧤さびダイヤフラムの 中心線で囲まれる部分をとった場合の計算值であるが， この領域としてそれぞれの外面で囲まれる部分をとった 場合の变形計算值も計算值 2 として破線で示した。

XA-Da を除いて，ぼの試験体においても奏験值はこ れらの計算值より大きい剛性を示している。その結果当 然のことながら計算值 2 の方が実験值に近く，さらに除 荷時の勾配でみると実験值と計算值 2 がほぼ一致してい る。したがって変形の計算においては，パネルジーンの 領域として柱フランジおよびダイヤフラムの外面で囲ま れる範囲をとるほうが奉情に合っていることになり，䩂

$$
\text { 表一6 耐力 計 算 值*1 }
$$

(単位: $\mathbf{t}$ )

\begin{tabular}{|c|c|c|c|c|c|c|c|c|c|c|c|c|c|}
\hline \multirow{2}{*}{ 試 } & \multirow{2}{*}{ 験 } & \multirow{2}{*}{ 体 } & & ル & \multirow{2}{*}{$\frac{y^{*}}{P_{P d}}$} & \multicolumn{2}{|l|}{ ン } & \multicolumn{2}{|c|}{ 济 } & \multicolumn{2}{|r|}{$i$} & \multirow{2}{*}{$\frac{\text { 柱 }}{P_{C y}}$} \\
\hline & & & $P_{P y 1}$ & $P_{P y 2}$ & $P_{P y 3}$ & & $\sigma_{\max }$ & $\sigma_{\max } / \sigma_{B}$ & $P_{B y}$ & $P_{B F}$ & $P_{B S}$ & $P_{\max } / P_{B F}$ & \\
\hline \multicolumn{3}{|c|}{$\mathrm{XA}-\mathrm{Sa}$} & 129 & 110 & 92 & 120 & 54.2 & 1.00 & 326 & 392 & 456 & 0.79 & 617 \\
\hline \multicolumn{3}{|c|}{$\mathrm{XA}-\mathrm{Da}$} & 274 & 233 & 193 & 252 & 40.1 & 0.74 & 326 & 392 & 456 & 1.22 & 617 \\
\hline \multicolumn{3}{|c|}{$\mathrm{XB}-\mathrm{Sa}$} & 240 & 200 & 160 & 202 & 49.7 & 0.96 & 327 & 396 & 540 & 1.15 & 847 \\
\hline \multicolumn{3}{|c|}{ XB-Se } & 240 & 200 & 160 & 202 & 45.9 & 0.88 & 327 & 396 & 540 & 1.06 & 847 \\
\hline \multicolumn{3}{|c|}{ XB-Sea } & 240 & 200 & 160 & 202 & 51.4 & 0.99 & 327 & 596 & 540 & 1.25 & 847 \\
\hline \multicolumn{3}{|c|}{$\mathrm{XC}-\mathrm{Se}$} & 347 & 276 & 205 & 325 & 50.5 & 0.96 & 509 & 638 & 852 & 1.21 & 1093 \\
\hline
\end{tabular}

*1 荷重は総て試験機より 0 加力量 $P$ 上して表示.

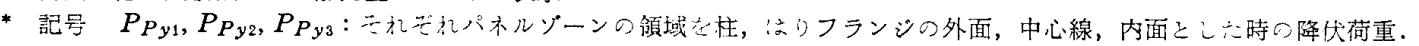

$P_{P d}$ : 学会门鋼構造設計規汻」に上る短期設計荷重.

$\sigma_{\max }:$ パホル領域を柱, はりフランジ心線内とした時の最大荷重時のパネル内引張主応力 $\left(\mathrm{t} / \mathrm{cm}^{2}\right)$

$\sigma_{B}:$ 柱ウェブ材の引張強さ $\left(\mathrm{t} / \mathrm{cm}^{2}\right)$

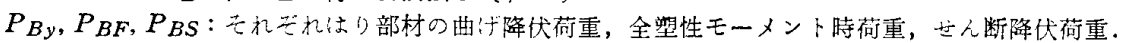

$P_{\max }:$ 最大荷重 (実験値)

$P_{C_{y}}:$ 柱の曲洋降伏荷重 
力算定におけるパネルゾーンの領域のとり方と矛盾する ことになるが，これは接合部パネルの変形が，実際には 純せん断的なものではなく，柱，はり部材による拘束の 影響があらわれた結果とみるべきで，上述のような単純 な計算で剛性を求めようとすれば必然的に大きな断面を 対象としなけ秃ばならなくなることを意味している。

\section{1 .3 補強プレートの効果}

接合部パネルに両面から補強 プレートを溶接した $\mathrm{XA}-\mathrm{Da}$ の降伏荷重実験值は，パネルゾーンの全断面積 を有効としたその計算值と比較するとかなり小さい。こ の実験值は同タイプの接合部パネルを補強しない試験体 XA-Sa の降伏荷重実験值の 1.76 倍となっており， XA-Sa を基準として考えると，全厚有効のパネル厚と しては $40 \mathrm{~mm} \times 1.76=70.4 \mathrm{~mm}$ に相当する。したがっ て降伏耐力からみた接合部パネル補強プレートの効率 $K$ は $K=(70.4-40) / 44=0.69$ ということになる。一 方図一3 において XA-Da のP-r関係をみると，初期 剛性については実験值と計算值がよく合っている。前述 のように他の試験体では接合部パネルの岡性の実測 值 は，せん断力だけを考えた単純な仮定による計算值より 大きくなっていることと対比してみると，このことは接 合部パネルの降伏荷重に関して上に述べた，補強プレ一 トが完全には効いていないという推定を裏付けていると 解釈される。この点をさらに検討するために，各試験体 の接合部パネルの $P-r$ 関係の包絡線からパネル内の平 均せん断応力度 $\tau_{\text {mean }}$ と $r$ の関係を求めて1つにまと めたのが図一4 である。これより XA-Da は他の試験体 に比へ，初期剛性もやや小さく，降伏の開始も早く，さ らに降伏後の剛性低下の割合も大きく，明らかに異な。 た挙動を示していることが認路れる。この図に基つい て補強プレートの効果を剛性の面からみると次のように なる。

補強する前のパネルプレート厚を $t_{p}$, 補強プレート厚 の合計を $t_{D}$ とすると補強したパネルプレートの板厚は $t_{p}{ }^{\prime}=t_{p}+t_{D}$ である。しかし補強プレートの補強效率を $K$ とするならば実質的な板厚 $t_{p}{ }^{\prime \prime}$ は $t_{p}{ }^{\prime \prime}=t_{p}+K \cdot t_{D}$ と なる。この場合 $t_{p}{ }^{\prime \prime} \mid t_{p}{ }^{\prime}=\alpha か ゙$ XA-Da の $\tau_{\text {mean }}$ のそ の他の試験体の $\tau_{\text {mean }}$ に対する割合と同じになるはずで ある。図一4について調べると，パネルの変形量でみて 塑性率 5 程度まで $\alpha \doteqdot 0.80$ でその後幾分低下し，塑性 率 15 程度で $\alpha \fallingdotseq 0.75$ 位になっている。したがって， $t_{p}=40 \mathrm{~mm}, t_{D}=2 \times 22=44 \mathrm{~mm}$ として補強プレートの 補強効辩を求めてみると $\alpha=0.80$ に対して $K=0.62$, $\alpha=0.75$ に対して $K=0.52$ となる。すなわち剛性面か らみた場合にはすみ肉溶接によって周辺を接合部パネル に固定した補強プレートは本実験で扱ったような形状， 寸法についてはその厚さ分の 60\%(パネルの変形の小 さいうち) 50\% (パネルの変形が大きくなった場合) 程 度しか効かないということになり，降伏耐力に対する前 述の結果と大体同様の傾向が認められる。

なお，図一4より補強のないパネルプレートの挙動 は，試験体間でプレート厚がかなり大幅に変わっている にも拘らずその差はあまり大きくなく，工学的な見地か らみればすざてほぼ同じ挙動をしているとみることが できる。

\section{2 骨組の耐力と変形}

\section{2 .1 耐 力}

各試験体について柱・はり部材の降伏荷重およびはり 端部が全塑性モーメントに達する時の荷重を計算した結 果を表一 6 , 図一2 に示してある。計算值と実験值を比 べると，はりの降伏荷重はいずれも実験值の方が計算值 より小さい。この点を明確にみるために，たて軸に柱に 作用するせん断力 $Q$, 横軸に柱の部材角 $R$ をとって各 試験体の全体変形の包絡線を図一5にまとめた。試験体 相互の比較のため，たて軸のせん断力ははりの降伏耐力 に相当する值 $Q_{B y}$ で除して無次元化してある。この図 には接合部パネルの降伏荷重計算值 $P_{P y z}$ に対応する值 が矢印で示してあるが，この図をみるとその矢印のあた

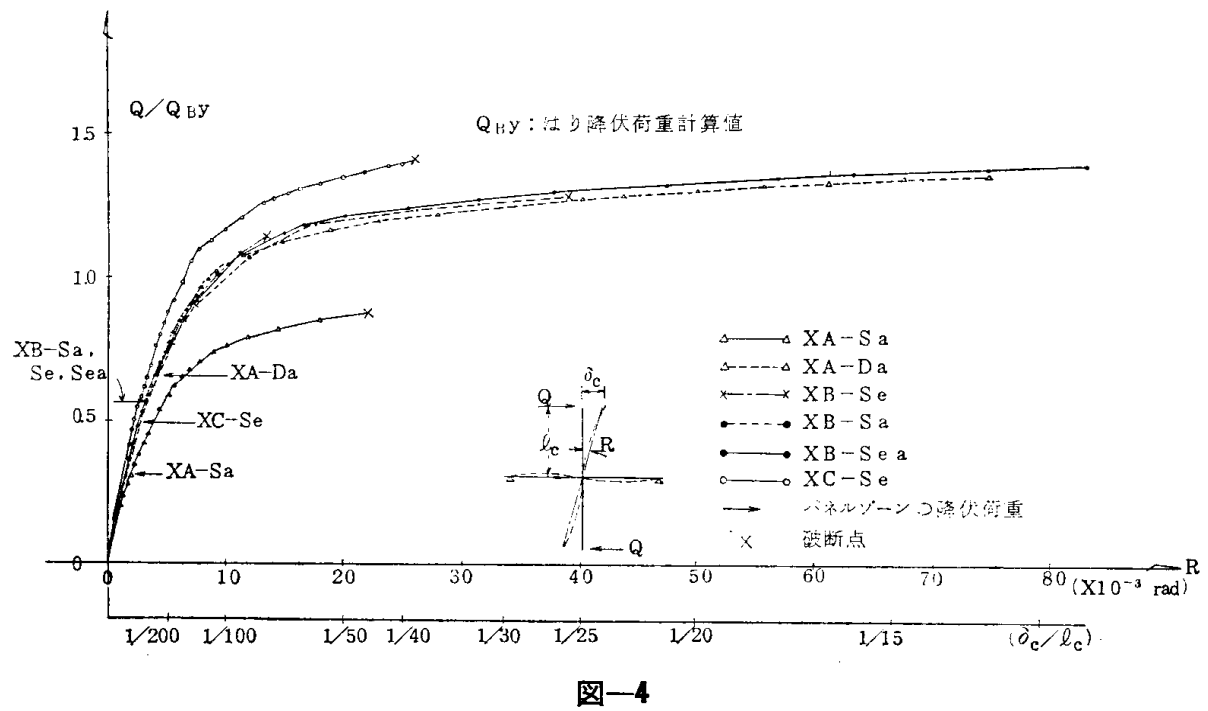




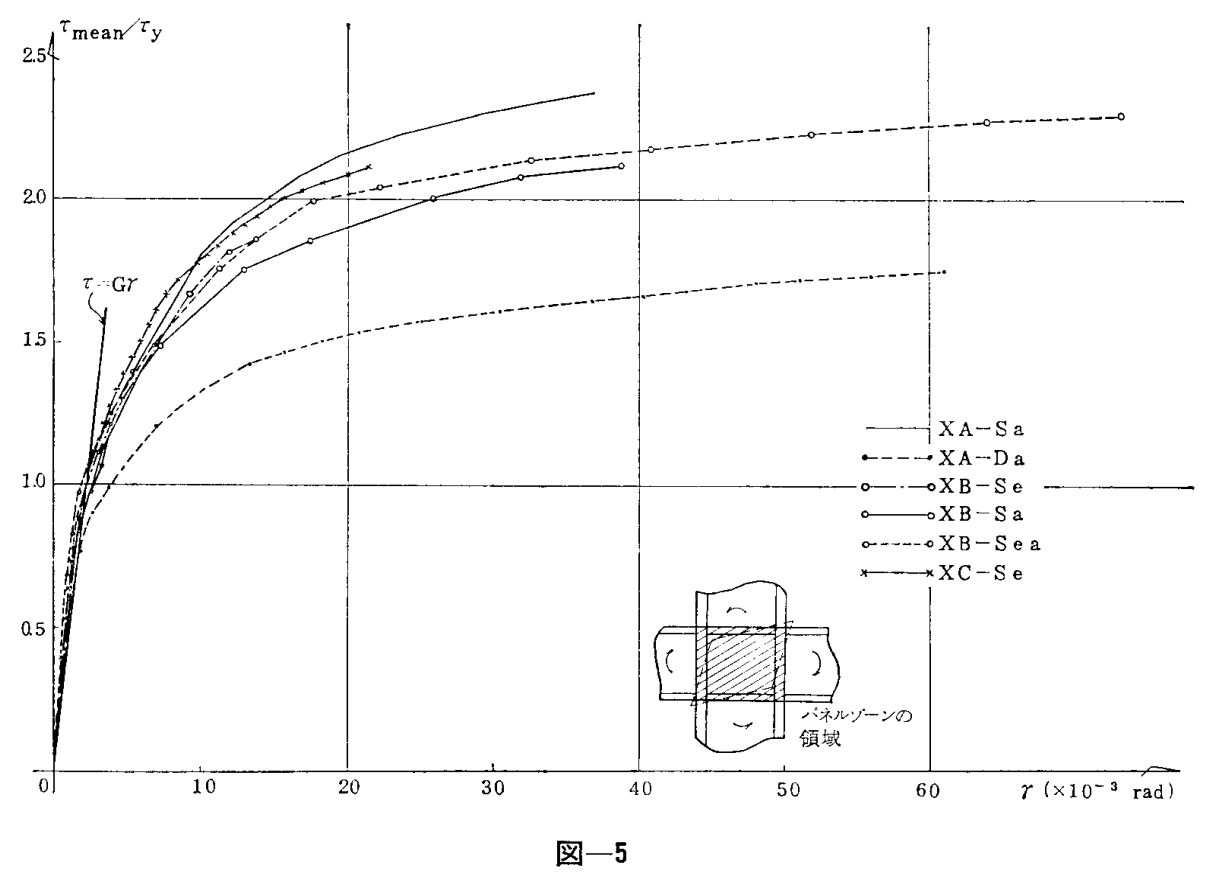

りで一度わずかに剛性の変化がみられるが，XA-Saを 除いて大体は $Q / Q_{B y}$ が $0.85 \sim 0.9$ まで大きな剛性低 下はみられない。 $Q / Q_{B}=0.85 \sim 0.9$ 位から認められる 降伏現象は，はりの降伏によるものと考元られる。すな わち本実験の試験体がいずれもはりの耐力に比べ接合部 パネルの耐力が約半分程度であるため, 接合部パネルが 早期に降伏した結果この部分の変形増大によって柱，は り部材とくにはりフランジの溶接部周辺に局部的な 2 次 曲げが作用してはりの降伏を早めるものと思われる。し かしこの程度の耐力低下は全体の挙動としてみれば, XA-Sa を除いては実用的にとくに問題となるほどでは ないとみることができよう。

XA-Sa は接合部パネルの降伏耐力がはりの降伏耐力 の $1 / 3$ 以下と極端にバランスが悪いために接合部パネル 降伏の影響が顕著にあらわれたと考えられる。この点 は，柱，はり部材に同じ形鋼を用いた XA-Sa とXADa について，それぞれの全体変形の測定值からパネル ゾーンの変形による影響量 (実測值)を除いたものを比 較した図一6によってみれば明らかである。すなわちこ

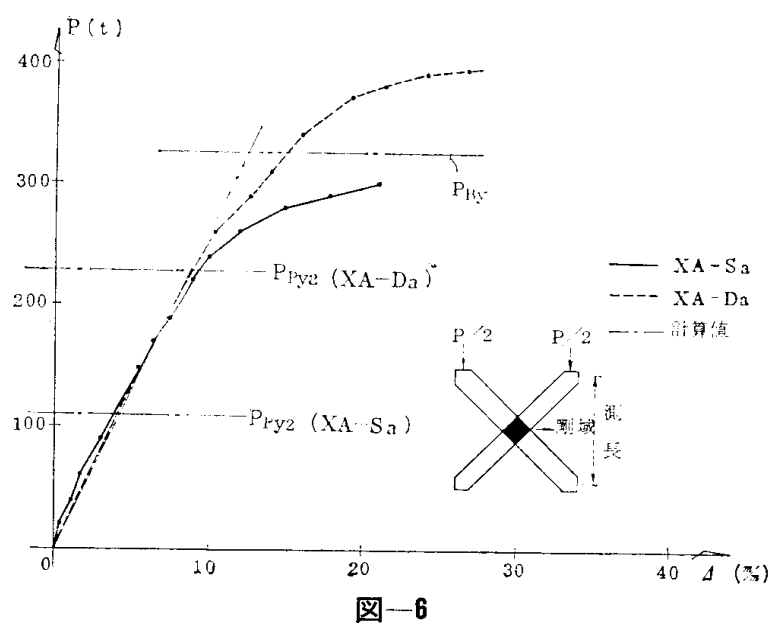

こに示す変形量は，一応はりと柱の変形のみによる全体 変形であると解釈できるので，XA-Sa とXA-Da は本 来同じ変形となってよいはずであり，図一6 にみられる 差は接合部パネルの変形による影響であると結論され る。

結局，以上の考察より，接合部パネルの降伏耐力がは りの降伏耐力より小さい場合，骨組全体としての耐力は いずれにしても接合部パネル降伏の影響をらけることに なるが，前者が後者の $1 / 2$ 以上あれば実用上さほど問題 とならないと考えられるのに対し，前者が後者の $1 / 3$ 以 下となるとかなり問題があるといえる。

各試験体の最大荷重は，接合部パネルが破断した XA-Sa を除いて， はり部材の全塑性モーメント時荷重 の 1.06 1.25 倍となっているが，このらちはりフラン ジと柱フランジの溶接部で脆性破壊を起こしたもので は，この值は 1.06〜1.21 倍となっており，脆性破壊を 生じていない試験体についての值 $1.22 \sim 1.25$ 倍より小 さい点は注目すべきであろう。

\section{2 .2 変形々勒性}

本実験では柱，はりの変形を分離せず，骨組全体の変 形 $\Delta$ を測定したが，この変形は次式であらわされる。

$$
\Delta=\frac{1}{\sqrt{2}}\left\{\delta_{B b}+\delta_{B s}+\delta_{C b}+\delta_{C s}+r\left(l_{B}-h_{B} / 2\right)\right\}
$$

ここで $\delta_{B b}, \delta_{B s}, \delta_{C b}, \delta_{C s}$ はそれぞれ接合部から外の 部分のはり，柱の曲げおよびせん断変形量であり， $l_{B}$ は パネル中心から加力点をでのはり長さ， $h_{B}$ ははりせい である。上式に対応する計算值を図一2 に示したが，こ れをみると実験值の方が計算值より幾分剛性が大きいこ とが認められる。図一6にみられる実験值と計算值の初 期剛性の一致の程度からみて，これは前述の接合部パネ ルのせん断変形角の実験值と計算值の違いに基づくもの 
と推定される。

構造物の勒性は, 最大塑性率 $\left(\mu_{\max }=\right.$ 最大変形量/降 伏荷重時変形量）を用いて検討することがよく行なわれ ている。表一5には各種の変形沉いて，それぞれの最 大塑性率が示してある。これらの值は general yield point 法によって定めた降伏荷重に対応する降伏時変形 量に基づいており，ほとんどの場合降伏現象がきわめて 緩慢に表われているので，必ずしも確定的な值とはいえ ず，数值的には一応の目安と考えた方がよいし，また最 大塑性率自体, 変形のとり方, 試験体の形状, 寸法など によって変わるものであるから，主として各試験体相互 の比較に重点をおいてみるべきであろうが，一忘この值 に基づいて検討する。

接合部パネルについてみると，その降伏耐力がはりの 降伏耐力に比へてて約半分位であるため，すべての試験体 で最大塑性率は 10 以上の值を示しているが，脆性破壊 の発生した XB-Se, XC-Se は他に比べてかなり小さ い。また接合部パネルで引張破断の生じた XA-Sa の值 も引張破断をしている以上かなりの変形を生じるはずで あると思われるにも拘らずその他の試験体に比べてあま り大きくない点が認められる。その理由は，この試験体 では接合部パネルの降伏耐力がはり部材のそれの $1 / 3$ 程 度とかなり小さいため, 接合部パネルの降伏後の変形 が，柱，はり部材によって拘束される度合いが，他の試 験体の場合より大きく, 破断が脆性的であったことによ るものと考えられる。これは図一6に関連して述べた， 接合部パネルの早期降伏による柱はり部材の降伏現象一 の影響と表裹の関係にあるといえよう。

全体変形についてみると, XB-Se, XC-Se の最大塑 性率の小ささが目立つ。とくに XB-Se の 5 という值は きわ立って小さく,このような勒性の少ない構造体を通 常の鋼構造物なみに扱うことは危険であるう。 XC-Se でも XB-Se に比べれば，最大塑性率は大きいといえる がその他のものに比べればやはり問題は残る。すなわち 絶対值として 8 前後の最大塑性率は構造物一般としてみ れば，一応満足すべき值と考えられるが，鋼構造骨組の 值としてはやや小さく，骨組の一部をとりだしたものに 対する值としてはこのあたりが一応の限界值ではないか と思わ机る。

はり部材のみについてみても最大荷重がはりフランジ 溶接部の脆性破壊で決っているものについては，そのよ らな破壊の生じていない場合に比べて半分またはそれ以 下となっていることは当然の結果とはいえ注目すべきこ とであろう。

\section{3 脆性破壊の発生と溶接方法}

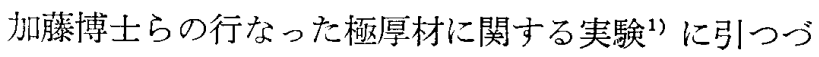
き本実験でも，はりフランジと柱との突合わせ溶接部に おいて常温下で脆性破壊の発生がみられた。加藤博士ら

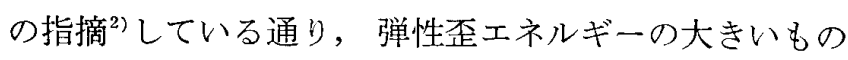
ほどきれつ伝播の状況は激しいようであり，きれつ発生 荷重もはり部材の全塑性モーメント時荷重 $P_{B F}$ の 1.06 〜1.21 倍で前記実験結果 ${ }^{2}$ とほぼ一致している。したが って極厚 $\mathrm{H}$ 型鋼を用いた柱はり溶接部では，溶接部の形 状, 溶接法, 溶接条件によって, 多少のずれはあっても $1.2 P_{B F}$ 程度の荷重時にはこの部分で脆性破壊の生じ る可能性はかなり大きくなると考穴られる。その場合設 計上の問題として, 最終的な脆性破壊の発生そのものを 構造上の欠陷之考えるのではなく，脆性破壞の発生まで に架構がぞの程度変形しらるかといら勒性の問題で考慮 するなどの配慮が必要となると思われる。

本実験でははりフランジと柱フランジとの突合わせ溶 接部に採用した溶接は, 手溶接, 消耗ノズル式エレクト ロスラグ溶接および消耗ノズル式エレクトロスラグ溶接 に手溶接による補強盛を行なったものの 3 種類である。 エレクトロスラグ溶接によるものは 2 体あって 2 体とも 溶接部で脆性破壊を起こしている。特に 1 電極で行なっ た XC-Se は強度的にも骨組の䩗性の面からみても, 不 満足な結果となっている。2 電極で行なった XA-Sa は 勒性面からみると, 使用可能の限界付近にあると考えら れる。

手溶接によるものは 2 体 (XA-Sa はパネル破断のた め最大荷重時のはり端溶接部の応力は小さいので除外す る）あって 1 体が溶接部から脆性破壊が発生している。 設計条件によって判断の基準は様々であるがこの試験体 程度のものであれば荷重および変形の面から一応満足で きるものとみてよいのではないかと思われる。エレクト ロスラグ溶接に手溶接による補強盛を施したものは 1 体 ではあるが, 加力の最後まで脆性破壊を起こさず，耐力， 䩚性ともに十分であった。これは手溶接によって最も応 力集中の大きい部分に熱処理を施したような治金的な効 果と, その部分の形状の修正といら幾何学的な効果によ る結果と考えられるが, 試験体が 1 体であり, 必ずしも 断定はできない。とくにエレクトロスラグ溶接を行なっ たあと, 完全に冷却した時点で予熱してから補強盛をし た T 形継手の実験では, 応力状態が多少違らにしても, 脆性破壊が発生したといら結果 ${ }^{12}$ あるので，このよう な補強盛をする場合も細心の注意が必要となろう。

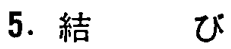

極厚 $\mathrm{H}$ 形鋼を用いて行なった柱はり接合部に関する 今回の一連の実験によって明らかとなった点は次のよう に要約される。

接合部パネルについて，

（i）接合部パネルの降伏荷重は，パネルゾーンの領 域として柱フランジおよびダイヤフラムの中心線で囲ま れる部分をとり, 接合部パルネ内の平均せん断応力度か ら計算する方法が，最も実情に適している。 
(ii) 接合部パネルの荷重一角変形曲線は $\tau$ - 関係で 表わした場合，このような極厚材についても，使用板厚 に関倸なく，大体同一の性状を示京。

(iii) 極愿 $\mathrm{H}$ 形鋼を用いた場合, 接合部パネルの最 大耐力はパネルプレートの主応力方向に扔ける引張破断 で決まると考えて算定することができそうである。

(iv) 接合部パネルの両側から補強プレートをすみ肉 溶接して, 補強する方法は, 酎力, 剛性両面からみて, $100 \%$ 有効とはいえない。本実験の場合でいえば，原パ ネル厚とほぼ同厚の補強した時の補強效率は降伏荷重以 下では 70\% 程度であり, 変形が増大するとさらに低下 し塑性率 15 位となると $50 \%$ 程度になる。

\section{架構全体について}

(i ）本実験のように，接合部パネルの幅厚比が小さ い上, 接合部パネルの最大耐力は，バネル内の引張主応 力によ,て決まるため, その降伏耐力注最大耐力に対し て十分な余裕を持つ。したがって，接合部パネルの降伏 耐力が，はり部材の降伏耐力より小さい場合には，接合 部パネルの降伏変形によって接合部周辺のはり, 柱フラ ンジが刑部的に早期に塑性域に大り，柱，はり部材の降 伏荷重に影響を与えるが，それでも前者が後者の大体 1/2 以上であれば，その影響仙小さく架構全体としての 耐力, 剛性面からみて, とくにパネル補強をしなくとも 一応実用的な設計が可能となるものと思われる。

(ii) 本実験のように極厚部材を使用すると，はりフ ランジと柱部材との溶接部に目立った欠陥がなくとも， はり部材の全塑性モーメント時酎力の $1.1 \sim 1.2$ 倍程度
の荷重が作用すると，この部分で脆性破壊が生じる叮能 性が大きい。

はりフランジと柱部材の溶接法についた

（i）はりフランジ厚が大きい場合, 加工の能率の点 から消耗ノズル式エレクトロスラグ溶接が使用されるこ とがあるが，その場合溶接のままで使らには十分な注意 が必要である。エレクトロスラグ溶接をした亦と，伸び の良い低水素系溶接棒で補強盛をすること汶有効と思わ れる。ただしこの場合も手溶接をする時期，その条件等 には適切な注意を払わなければならない。

(ii) 手溶接を用いる場合には, 予熱, 溶接棒, 溶接 条件などに十分な施工管理が行なわれれば，一応開題の ない接合部が得られるが，溶接工の技倆にも大きく影響 され，内部欠陥も生じやすいのでこの場台も十分な注意 が必要である。

\section{謝辞}

本実験に際して，早大鶴田明教授，東大梅村魁教授， 青山博之助教授, 伊藤勝助手上り種々有益な御指導, 御 助言を頂いた。また試験体の製作にあたって日本鋼管， 三菱重工業, 神戸製鋼所, 新興工業の各社の御協力を頂 いた。ここに深く感謝の意を表します。

\section{参考 文 献}

1）加藤 勉，森田耕次：「極厚鋼部材口脆生破填」日本這 築学会諭文報售集, No. 156, 昭和 44 年 2 月.

2) 加藤 勉, 森田耕次, 橋本健一：「極厚銅部材の脆性破 唗」(その2), 日不建築学会諭文報告集, No. 176, 昭和 45 年 10 月.

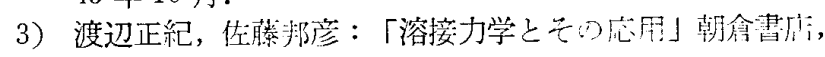
昭和 40 年. 
U.D.C. 624.042 .7

\section{EVALUATION OF EARTHQUAKE EFFECTS ON THE DEFORMATION OF MULTI-STORIED BUILDING BY GROUND MOTION AMPLITUDES}

(See Page 21)

by Dr. HIROYOSHI KOBAYASHI, Prof. Tokyo Institute of Technology and Dr. SUMIO NAGAHASHI, Assist., Tokyo Institute of Technology, Members of A.I.J.

U.D.C. $539.4: 624.078 .014 .2$

\section{EXPERIMENTAL STUDY ON BEAM-TO-COLUMN CONNECTIONS OF HEAVY STEEL SECTION MEMBERS}

by MASAHIRO TAKENAMI, TATSUHIKO SAITO, ATSUO TANAKA and NORIMASA ENOMOTO, Taisei Corporation, Members of A.I.J.

\footnotetext{
The statical characteristics of beam-to-column connections of heavy steel section members at lateral loading are experimentally investigated. The variable factors of this experiment were the size of section, the combination of beam and column members (beam flange thickness : $40.60 \mathrm{~mm}$, column flange thickness : 75, $90,125 \mathrm{~mm}$ ) and the welding method of beam flange to column flange (manual arc weld and simplified electroslag welding), so that eventually six specimens were used.

Brittle fracture was observed at the beam-to-column connection under room temperature in four specimens at ultimate stage of loading. In one specimen the brittle fracture tookplace at the center of the panel zone (the crossing area of beam and column members) in the principal stress direction, and in the other three spcimens it occured at thd butt weld of beam flange to column flange. Those brittle fracture took place at $1.06 \sim 1.21$ times of the full plastic strength of beam members. This kind of phenomenon was also reported another previous paper. Therefore it is concluded that the brittle fracture at the beam-to-column connection may take place very often at high stress level under lateral loading, when heavy steel section members are used.

The relation between the yield strength of the panel zone and that of beam member and the effect of reinforcement of the panel zone by doubler plate were also investigated.
}

U.D.C. 725.51 .011 .1

\section{FEASIBILITY-TEST OF ECONOMIC VIABILITY AND QUANTITATIVE RELATIONSHIP OF FACTORS IN REGARD TO INVESTMENT AND MANAGEMENT PLANNING IN PRIVATE HOSPITAL}

- Study on Test of Feasibility of Economic Viability in Hospital Building Planning No. 2-

by TAKESHI KOSHIBE, Part-time Lecturer of Tokyo Metro. Univ., Member of A.I.J.

This paper shows a way of test of economic viability in private hospital, and shows analysis of quantiative relationship of factors in regard to investment and management planning.

In the economic calculation, supposing four kinds of private model hospital with $50,100,200,400$ beds and using the analysis of the previous paper. 